\title{
Colombian Transitional Justice: The media discourse of the Peace Agreement and perceptions regarding its institutions
}

\author{
Justicia Transicional en Colombia: el discurso mediático \\ del Acuerdo de Paz y las percepciones sobre sus instituciones
}

\author{
Angélica Caicedo-Moreno \\ University of the Basque Country \\ angelicamoreno8_@hotmail.com \\ Pablo Castro-Abril \\ University of the Basque Country \\ pabloenrique.castro@ehu.eus \\ Wilson López-López \\ Pontifical Xaverian University \\ lopezw@javeriana.edu.co \\ Lorena Gil Montes \\ University of the Basque Country \\ lorena.gildemontes@ehu.eus
}

Citation/Cómo citar: Caicedo-Moreno, Angélica; Castro-Abril, Pablo; López-López, Wilson; Gil Montes, Lorena. 2021. "Colombian Transitional Justice: The media discourse of the Peace Agreement and perceptions regarding its institutions». Deusto Journal of Human Rights, No. 8: 51-82. doi: http://dx.doi.org/10.18543/djhr.2284.

Summary: Introduction. 1. We all want peace but not like this: Disagreements on notions of peace 2 . Social reconciliation in transitional contexts. 3. Media in the understanding of conflict and peace. 4. Objectives and hypotheses. 5. Study 1. 5.1. Method. 5.2. Design. 5.3. Data analysis. 5.4. Results. 5.5. Conclusions. 6. Study 2. 6.1. Method. 6.2. Participants. 6.3. Procedure. 6.4. Measures. 6.5. Results. 6.6. Conclusions. 7. General discussion. References.

Abstract: Colombia had the longest internal armed conflict in Latin America, and its government reached a peace agreement with the 
FARC guerrillas in 2016. This article explores the transitional justice social representations during the signing of the peace agreement (study 1) and their implementation, during 2019-2020 (study 2). The first study analyzes the news related to the institutions created from the peace agreement during 2016. The second study explores different psychosocial variables associated with its two most controversial institutions, the Truth Commission (TC) and the Special Jurisdiction for Peace (JEP) during 2019-2020, after the beginning of its work. The findings revealed that news articles from two principal Colombian newspapers illustrate two anchoring categories of transitional justice with an emphasis on victims, while the political position of the newspaper suggests possible disagreements on what peace entails. Surveys showed that political position and victimization are crucial for the approval and support of the TC and the JEP, as well as correlated with the level of media consumption regarding these institutions.

Keywords: Transitional Justice, Media Analysis, Collective Violence, Peacebuilding.

Resumen: Colombia tuvo el conflicto armado interno más largo en Latinoamérica y alcanzó un acuerdo de paz con la guerrilla de las FARC en 2016. Este artículo explora las concepciones de justicia transicional durante la firma del acuerdo de paz (estudio 1) y su implementación durante 2019-2020 (estudio 2). El primer estudio analiza las noticias relacionadas con las instituciones creadas a partir del acuerdo de paz durante 2016. El segundo estudio explora diferentes variables psicosociales asociadas a sus dos instituciones más controvertidas, la Comisión de la Verdad (CV) y la Justicia Especial para la Paz (JEP) durante 2019-2020, después del inicio de su trabajo. Los resultados revelaron que las noticias ilustran dos categorías de anclaje de la justicia transicional con un enfoque especial en las víctimas, mientras que la posición política de los periódicos sugiere posibles desacuerdos sobre lo que la paz implica. Las encuestas mostraron que la posición política y la victimización son cruciales para la aprobación y el apoyo de la CV y la JEP, así como se correlacionan con el nivel de consumo de los medios de comunicación en relación con estas instituciones.

Palabras clave: Justicia Transicional, Análisis de Medios, Violencia Colectiva, Construcción de Paz. 


\section{Introduction}

Colombia had a long internal armed conflict that left millions of victims, and currently, it faces a post-peace agreement context with the guerrilla known as Revolutionary Armed Forces of Colombia (FARC-EP for its acronym in Spanish) (Trejos 2013). Generally, the transition from a violent context to one of peaceful coexistence involves disagreements on the most appropriate way to approach the end of violence and achieve a peaceful society (Kelman et al. 2018). The referendum results for the peace agreement in 2016, where $51 \%$ of voters showed their rejection, are an example of this. In a context of intense public debates on the conflict resolution and the signing of the agreement despite its rejection, knowing the impact of the transitional justice model becomes essential for searching peaceful coexistence and construction of peace cultures (Staub 2012; Arnoso et al. 2014).

Transitional justice is used as a broad term to describe the approaches to the transition process from violent conflicts to more peaceful and democratic states while dealing with the past and its aftermath. Its main objectives are to make amends for past wrongs, restore the dignity of victims, and provide justice in a transitional context through a diverse spectrum of mechanisms such as tribunals and truth commissions (Buckley-Zistel et al. 2015). Moreover, this model combines restorative and retributive justice to develop sustainable peacebuilding while including citizen participation in the design and implementation of the mechanisms. It has four main aspects related to legal, psychosocial, socioeconomic, and political justice (Lambourne 2009).

Due to the length and massive victimization of the Colombian conflict, the peace agreement addresses possible solutions through transitional justice mechanisms to multiple structural and socioeconomic problems that caused the armed conflict and enabled its perpetuation. However, this peace agreement sparked a public debate regarding its legitimacy, consequences and actors involved due to a referendum in 2016 where most citizens rejected the peace agreement. Several authors have found that this debate has a political origin based on the deep arguments among the country's elites regarding the peace agreement. This political division ended up being a central factor between supporters of the agreement (from more liberal and centerleft currents) and its detractors (from the conservative and center-right wing) (Matanock and García-Sánchez 2017; Bohigues, Rivas \& García 2021). The rejection of the agreement through its referendum reflected the national debate and animosity among the population (Matanock and García-Sánchez 2017). 
One of the most important and controversial points of the agreement is the victim's emphasis, which created a system comprising three institutions: the Special Jurisdiction for Peace (JEP for its acronym in Spanish), the Truth Commission (TC), and the Search Unit for the Disappeared. The system emphasizes measures to guarantee the victims' rights to truth, justice, reparation, and non-repetition (Jurisdicción Especial para la Paz 2019).

The Colombian case is of particular interest to transitional justice studies since it features a peace process rejected by a visible percentage of the population, a division in the political elites caused by it, as well as a current government with a defensive position towards its implementation (Flores and Vargas 2018). In this scenario, disagreements on the conceptions of peace and the appropriate way to address the armed conflict that different political and social sectors have had, have been a challenge for the agreement implementation.

\section{We all want peace but not like this: Disagreements on notions of peace}

Once a society has suffered collective violence, it is likely to assume that the search for peace is, at least in part, a common goal for the affected population. The concept of peace is not always global, nor does it have a shared meaning understood in an obvious way (Galtung 1969). Usually, the transition from a violent context to one of peaceful coexistence involves disagreements about the most appropriate way to approach the end of violence. These discrepancies do not necessarily imply that the groups involved do not want peace but that the conceptions and methods to achieve it differ (Kelman et al. 2018). These conceptions of peace are influenced by how the conflict is lived, the group's representations involved, and the current historical moment of the society (Leshem and Halperin 2020). Authors find that lay theories of peace explain differences in citizens' preferences for conflict resolution. In addition, other studies found that the level of moral competence affected the preference between restorative and retributive justice, as well as differences in the beliefs regarding justice depending on the socioeconomic position (Gutiérrez-Romero et al. 2020; 2021).

Likewise, lay theories of peace are related to peace expectations. Leshem (2017) finds that identifying to the right-wing of the political spectrum predicts low peace expectations and a preference for less concrete peace definitions that allow more subjective interpretations 
and avoid the psychological cost of conceptualizations that recognize the others and their interests.

On the other hand, several authors examined the attitudes and perceptions towards transitional justice mechanisms in Latin America. These studies explored social representations of the past and transitional justice rituals and found that political position is a relevant factor in evaluating the usefulness and achievement of the objectives of transitional justice institutions. In general, people identified with the right-wing, downplaying the importance of the construction of collective memory and the need to speak openly about the events of the conflict. This effect appears in armed conflicts related to right-wing dictatorships or guerrilla involvement (Arnoso et al. 2015; Cárdenas et al. 2016; Espinosa et al. 2016; Mathias et al. 2020).

\section{Social reconciliation in transitional contexts}

Transitional justice aims to provide tools and create spaces for peaceful coexistence and, ultimately, a complete process of social reconciliation. Socio-structural, relational and social identity changes are essential to achieve inter-group reconciliation, both as a process and an outcome. Firstly, it implies a closer relationship between the groups that have been involved in a conflict and seeking a common re-signification of beliefs and objectives. Secondly, it entails achieving the demands of the affected groups through the perceived attainment of justice, truth, and reparation (Rettberg and Ugarriza 2016). Consequently, social reconciliation relates to the psychosocial recovery from the harm suffered through the need's satisfaction of the victims, the perpetrator groups, and the general population (Alzate and Dono 2017).

Reconciliation requires the formation of new social beliefs that describe the multidimensional nature of peace, specifying the conditions and mechanisms for its achievement, realistically outlining the benefits and costs of its attainment, and emphasizing the meaning of living peacefully and the conditions for its maintenance (LópezLópez 2017; López-López et al. 2021).

Nowadays, societies that have suffered collective violence express the urgency of creating appropriate spaces for social reconciliation based on recognizing the damage caused, the reintegration process, and creating a peaceful culture with an inclusive memory (Gluecker et al. 2021). Countries trying to overcome their history of conflict have created transitional mechanisms such as the TC established in South 
Africa, Argentina, or Chile (Velez et al. 2020). Similarly, in Colombia, the TC and the JEP were created as part of the peace agreement.

\section{Media in the understanding of conflict and peace}

Media communication acts as a socialization agent that can contribute towards respect for life and ending violence, although it has also been found to contribute to social conflict (Igartua 2011). However, the study of discourse in conflicts has shown that it can be a fundamental tool in peace culture construction since it allows the visualization of the structures of sociopolitical, and economic reality. The media can grant spaces to issues or actors while making others invisible, influencing the perception and social construction of reality since they are not limited to the description of facts (López-López et al. 2014). Consequently, the perception of armed conflicts and transitional processes towards peace may be conditioned by the media's handling of information (López and Sabucedo 2007).

Therefore, in the context of political violence, these communicative agents are essential for disseminating beliefs about conflict and peace. As found in the study on El Tiempo, the largest newspaper in Colombia, where warlike or pacifist discourses for conflict resolution were identified (López-López et al. 2014). Likewise, Rincon-Unigarro et al. (2020) found a change towards peace in the beliefs that promoted the conflict in Colombia during the peace negotiations.

\section{Objectives and hypotheses}

This study sought to explore the influence of political ideology on the social representations of transitional justice and the population's attitudes towards its institutions. We explored the consensus and dissent of the Colombian population through two methodologies. The first study analyzed news articles published by two major media outlets of different ideological currents during the proposal of the peace agreement, its referendum, and its subsequent signing in 2016. The second study evaluated people's level of knowledge and approval of the institutions, attitudes towards collective memory, social sharing, the perceived emotional climate of the country, institutional trust, and social reconciliation. In both cases, the data were analyzed regarding the political ideology of both the participants and the media. 
Thus, we expect that newspapers portray transitional justice differently according to their political positions. El Tiempo, as a conservative newspaper, is more likely to emphasize the work of political and armed leaders as the main actors to achieve peace (LópezLópez et al. 2014); it will probably exhibit lower expectations of peace and a preference for lesser concrete definitions of peace (Leshem 2017). On the other hand, El Espectador from a more liberal current will likely focus on dialogue as an alternative solution to the use of violence (Grajales \& Martínez 2020), and by contrast, will exhibit higher expectations of peace, with more complex definitions where the other and their interests are recognized (Leshem 2017).

Moreover, as seen in previous studies of transitional justice in Latin America, we expect that the political position of participants will be related differently to the variables regarding social sharing, attitudes towards remembering the past, and transitional justice institutions. Similarly, we expect knowledge and approval of these institutions to be higher according to the level of victimization and political position, with direct victims and people on the left approving more and knowing more about the institutions. Finally, people on the right-wing will likely agree more with forgetting the violent past, while people on the leftwing will show higher agreement with remembering the past.

\section{Study 1}

\subsection{Method}

Study 1 is a textual analysis of news related to the peace agreement and its institutions in Colombia during 2016, published in the two most circulated newspapers in the country. The two leading newspapers with national distribution were selected: El Tiempo and El Espectador, with different political positions. El Tiempo belongs to Luis Carlos Sarmiento Angulo, one of the most economically powerful men and owner of one of the largest banking conglomerates in the country (Forbes 2020). During the last decades, this newspaper remained closely linked to the most conservative political elites in the country, and previous findings showed a preferably warlike discourse emphasizing military triumphs, a competitive perspective of victory and defeat between groups, the leaders of legal and illegal groups, as the only decisive actors, among other warlike features (López-López et al. 2014). Recently, this newspaper made public its preference for the current president Ivan Duque during the 2018 elections (Editorial 2018), belonging to a 
conservative and right-wing political party characterized by its rejection of the peace agreement (Kajsiu 2019).

On the other hand, El Espectador identifies with the defense of liberal ideas since its foundation. Historically, this newspaper is known for its emphasis on critical analysis, evidenced by the various attacks it has suffered from institutional and illegal groups (Alarcón 2020). Although this newspaper also belongs to a private business group, it has successfully maintained its editorial independence, and during the last few years, has shown public support for peace and reconciliation initiatives in the country (El Espectador 2021). Grajales and Martínez (2020) conclude that during the peace process between 2012 and 2016, the newspaper supported the president and legitimized strategies such as dialogue for resolving the armed conflict and negotiations for an alternative solution to the use of violence.

In conclusion, although it is evident that neither of them openly positions themselves in the political currents of the left or right, their coverage and discourse of the armed conflict reveal different preferences regarding conflict resolution. Thus, each newspaper may represent more conservative tendencies whose solution to the conflict is mainly military (El Tiempo) and more liberal tendencies that opt for lesser use of confrontational strategies and more spaces for dialogue and negotiation (El Espectador).

\subsection{Design}

We retrieved 300 news articles published during 2016 from the websites of El Tiempo (50\%) and El Espectador (50\%). The keywords that led the search were: Peace $(n=100)$, Truth $(n=100)$, and Victims $(n=100)$. These words portray the work of the three institutions created by the Colombian transitional justice system, which in turn are words that can globally represent the transitional process. First, Peace is one of the main aspects of the Special Justice for Peace and one of the words with the most impact in the national debates (e.g., 'peace' agreement, 'peace' negotiations). Second, the keyword Truth is the most significant from the Truth Commission and is part of the public discussions regarding the collective memory process. Finally, the word Victims conveys the work of the Search Unit for the Disappeared and captures the central role of victims in the Colombian process. The keywords and timeframe were the only filters used in the media websites to retrieve the news articles. Table 1 shows the type and size of news articles collected. 
Table 1

\section{News type and size, its modalities, and percentages from total sample}

\begin{tabular}{|l|l|l|c|}
\hline \multicolumn{1}{|c|}{ Variable } & \multicolumn{1}{|c|}{ Definition } & \multicolumn{1}{c|}{ Modalities } & \% from Total Sample \\
\hline News & Type of news & News & $73,00 \%$ \\
type & according to its & Interview & $11,67 \%$ \\
& content & Opinion article & $10,67 \%$ \\
& & Feature story & $3,33 \%$ \\
& & Editorial & $1,33 \%$ \\
\hline \multirow{2}{*}{ Size } & News size in & Quartiles: & \\
& number of words & $1: 0-478,50$ & $25 \%$ \\
& & $2: 479-719,50$ & $25 \%$ \\
& & $3: 720-1212,5$ & $25 \%$ \\
\hline
\end{tabular}

Source: Table by authors.

\subsection{Data analysis}

The software Alceste for lexical analysis (Reinert 1983, 1990) analyzed the corpus of the texts published by the newspapers. This method reduces the problems of reliability and validity in the text analysis (Klein and Licata 2003; Reinert 1996). Moreover, lexical analysis is valuable when examining collective thinking as its object of study is the analysis of language or discourse as a shared representation rather than the text's semantic meaning (Allum 1998). The lexical analysis of the media allowed us to examine the dissemination of information produced by the government and other institutions to the public.

Alceste performs segmentation of corpus into Elementary Contextual Units (ECUs)and crosses them to create a contingency table. A square-distance matrix is formed from this table, meaning that two ECUs are close if they share some of the words analyzed (Reinert 1996). Ultimately, a descending hierarchical cluster analysis produces classes of ECUs that best differentiate the vocabulary. By doing this, Alceste helps in the text interpretation as it extracts classes of words that co-occur and are best discriminated from each other, allowing researchers to identify the primary lexical universes of the corpus (Reinert 1993). Moreover, Alceste calculates the relation between levels of independent variables and the lexical classes using independence tests. In this study, the independent variables were Publication source, Type of news, and Size of articles. 
After introducing the raw data in Alceste, the most significant vocabulary in each class was selected by three criteria: a) an expected value of the word higher than $4, b)$ proof of association of the Chisquare tested against the class $\left(X^{2} \geq 3.84(p=0,05) ; d f=1\right)$, and $\left.c\right)$ the word occurs in the class with a frequency of $50 \%$ or more (Camargo and Bousfield 2009). Retrieved data was analyzed in Spanish, and results were translated for publishing purposes by trained researchers.

\subsection{Results}

The entire corpus had 276497 words, with 20912 unique words. The descending hierarchical analysis divided the corpus into 6781 ECUs, 5277 (77\%) were analyzed, and eight kinds of ECUs were extracted from the most significant vocabulary in each class. Figure 1 displays the results of the analysis.

Results showed two main clusters that reveal the most salient issues regarding the peace agreement in 2016. Each cluster shows a branch or theme composed of different classes with a set of typical words and segments (see Fig. 1). The first cluster linked to the aspects of the transitional process (i.e., needed steps or changes to achieve peace) is composed of Classes 2 (Peace Agreement), 7 (Reaching peace), 8 (Power relations), 4 (Collective reparation), and 1 (Justice), while the second cluster related to the stories and events during the armed conflict is composed of Classes 5 (Victim stories), 6 (Place memories) and 3 (Violence testimonies).

The first cluster Transitional Process reveals the main aspects of public concern regarding the peace agreement, more specifically, it gathers the overall objective of peace and three of the primary points in the agreement, the solution to the illicit drug problem, the victim focus which aims for justice, truth and reparation, and the signing and referendum of the peace agreement.

This main cluster begins with Class 2 with a weight of $21.51 \%$ and is labeled as 'Peace agreement' as it describes the main events and political steps from the prior negotiations, the referendum, and the signing of the agreement. The independent variables highly associated with this class are small (size: quartile 1 and 2) news articles published by El Tiempo (see Fig. 2).

'Peace agreement' refers to former president Juan Manuel Santos and the guerrilla FARC during the negotiations in Havana. It addresses the referendum and agreement signing coverage focusing on the achievement of the ceasefire as a precondition to the peace process. 


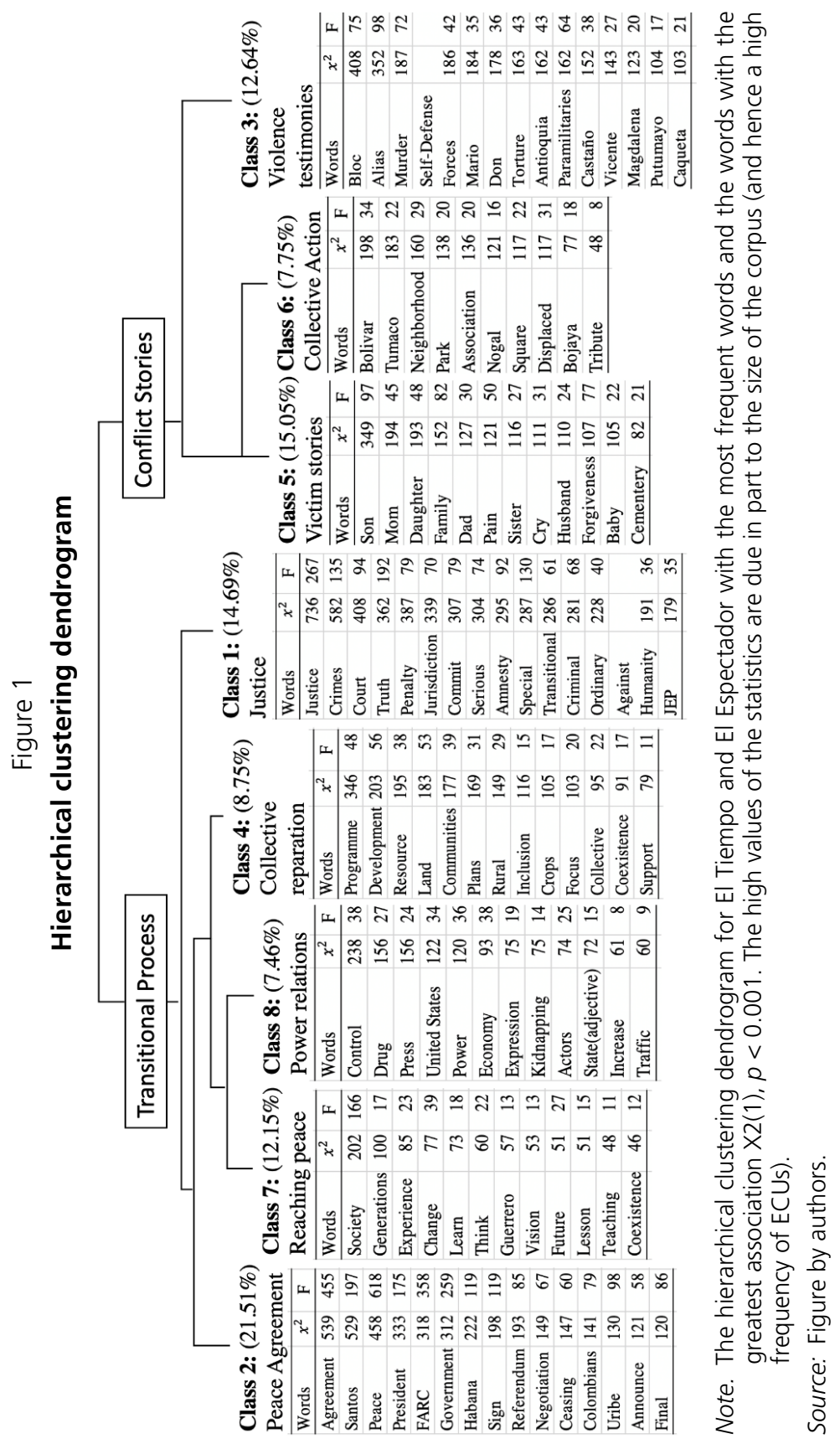

Deusto Journal of Human Rights 
Moreover, this class refrains from extensive analysis (i.e., answers to why?) and instead explains how the peace agreement will unfold practically. As seen in the following most characteristic text segment (ECU): "Both president Juan Manuel Santos and the guerrilla chief, Timochenko, relied on the $6,377,482$ Colombians who voted yes for saying that, despite the no majority, they maintain their will for peace" $\left(X^{2}=46\right.$, El Tiempo, news article, size quartile 3$)$.

Following the Transitional Process main cluster, the second class emerges, Class 7 with $12.15 \%$ and labeled as 'Reaching peace'. This class describes the needed social transformations and its expectations regarding the future after the agreement that is society must be willing to act: think, learn, change, and teach with the likely aim of peaceful coexistence (significant words of this class, see Fig. 1). It is highly associated with interviews and in lower levels with larger pieces (Size quartile 4), El Espectador, and opinion articles (see Fig. 2).

'Reaching peace' illustrates other countries' experiences and peace processes as a strategy to analyze the Colombian agreement. These news articles share lessons learned in similar contexts and discuss the expectations for change in the future. Through more extensive analysis, the armed conflict is presented as a longitudinal and historical process that affects both past and future generations, raising the need to understand the historical past and address the necessary changes in the pursuit of peace: "The past continues to have an enormous impact on the present, shaping it to a large extent. So post-conflict becomes a kind of national mythology, something that people need to believe in, but people are not looking realistically at what the challenges are and how they have been shaped by the past." ( $X^{2}=28$, El Espectador, interview, size quartile 4).

Related to the second class of the first cluster, the third class, Class 8 , with a weight of $7.46 \%$, is called 'Power relations' since it describes the new conflict dynamics related to territorial and economic control with the demobilization of the FARC guerrillas and the release of their territories. Like the previous class, it is associated with interviews and long-form articles (size quartile 4) from El Espectador (see Fig. 2). 'Power relations' discuss drug trafficking, the role of the United States on Colombia's economic and security relations, state neglect, and the continuation of violence such as kidnappings and threats to freedom of expression. Specifically, it mentioned other armed actors such as paramilitary groups and the use of violence to maintain control over the population: "the demobilization of the guerrilla added to the historical absence of the state and the presence of other illegal groups, gives way to new logics of territorial control" $\left(X^{2}=42\right.$, El Espectador, news article, size quartile 3). 


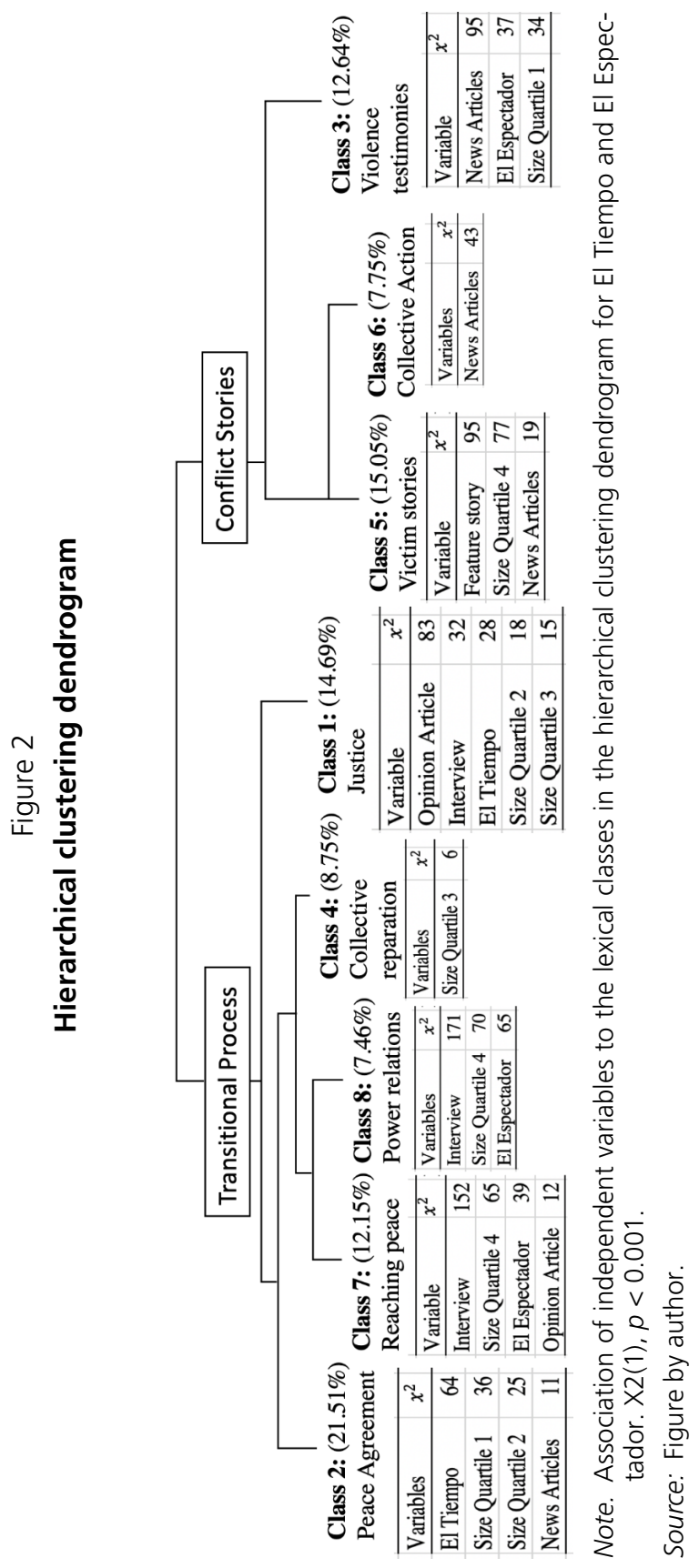


The third class of the Transitional process cluster, Class 4, with a weight of $8.75 \%$, is called 'Collective reparation' since it describes the support and development programs focused on the victims and their communities to restore their resources and territories. These plans have territorial, gender, and victim assistance approaches.

Moreover, it illustrates the institutional efforts from the peace agreement to materialize support to the vulnerable and rural populations affected by the armed conflict generating conditions of inclusion and reparation that promote peaceful coexistence. As seen in the following text segments (ECU): "it must provide assistance and support to the victims. The FARC is committed to making reparations to the communities they affected, and they will be able to do so by participating in infrastructure reconstruction works, in demining programs, in the substitution of illicit crops" $\left(X^{2}=60\right.$, El Tiempo, news article, size quartile 4).

Finally, the last class of the first cluster (Class 1) is labeled 'Justice', weights $14.69 \%$, and describes the processes of justice, truth, and non-repetition. As well as debates the efficacy of the transitional justice system towards these objectives. It is associated with opinion articles, interviews, and El Tiempo (see Fig. 2).

The discourse of this class uses extensive legal language to explain the functioning of transitional justice and the creation of the JEP, its differences with ordinary justice, and the guarantees that it can have against impunity for crimes against humanity. An example: "the magistrates who will form the special peace tribunal will be in charge of investigating, judging and punishing the perpetrators of serious crimes, and will have the responsibility to ensure that there is no impunity" ( $X^{2}=70$, El Tiempo, news article, size quartile 2$)$.

The second cluster, Conflict Stories, reveals the violent events that occurred during the conflict, their social effects on the victims, the search for the truth through the testimonies of the armed actors, and the memory restoration of the affected regions.

This second cluster begins with class 5, named 'Victim stories' with a weight of $15.05 \%$, and emphasizes the personal and family stories of the victims that portray the violent events with a high emotional charge. This class portrays the horrors experienced, reflects the emotional effects suffered and the search for the forgiveness of some of them. This class is associated with feature stories and long articles (size quartile 4) (See Fig. 2).

This coverage emphasis is human and personal, publishing the firsthand story of the victims, including details about the violent events, their murdered family members, and the pain experienced during the 
conflict: "They shot more, but I ran to look for my children; I only thought about the kids. I couldn't stop crying. I found my six children and my husband, but I was missing one of them, and I thought they had killed him" ( $X^{2}=77$, El Espectador, news article, size quartile 3 ).

The next class in this cluster is called 'Collective action' with a weight of $7.75 \%$ and describes the collective demonstrations related to the memory construction about the armed conflict in the affected places and different squares or meeting points of the country. Their objective is to honor the victims of violent events that have impacted the conflict's history, such as the terrorist attack on El Nogal Club, the massacre in Bojayá in 2002, and the multiple violent events in the Tumaco region. An example of the most representative textual units reinforces the above: "They have been in libraries, galleries and universities in Bogota, Cartagena, Medellin, Bordeaux, France, and Switzerland. They became memory guardians of the war in the Montes de Maria." ( $X^{2}=56$, El Espectador, news article, size quartile 4).

Finally, class 3 emerges from the second cluster, Conflict Stories, with a weight of $12.64 \%$. It is called 'Violence testimonies' and describes the statements of members of armed groups that have benefited from previous demobilization processes, in which they indicate facts, places, perpetrators, and victims. This class is associated with news articles from El Espectador (see Fig. 2).

The last peace process in Colombia was focused on the demobilization of paramilitary-armed groups in 2002, and this class collected the resulting testimonies: "In 2009, in a justice and peace hearing, another paramilitary, Freddy Rendon Herrera, alias El Aleman, testified that Castaño had ordered Don Berna and his gang to assassinate Garzon as a favor to Army officers" ( $X^{2}=73$, El Espectador, opinion article, size quartile 2 ).

\subsection{Conclusions}

The textual analysis of the 2016 news from the first study reflects the complexity and multidimensionality of the peace-building process. In 2016, Colombia was going through a reshaping of the armed conflict, and the actors involved initiated a social reconciliation process through a peace agreement. However, other illegal armed groups such as paramilitaries and drug trafficking networks began to have greater relevance due to the state's inability to address the structural needs of the most affected areas by the conflict (Fundación Paz y Reconciliación 2019). Thus, the news revealed a wide range of issues 
related to transitional justice, a concept that provoked debates from the beginning thanks to the large and complex changes proposed in the peace agreement. These topics delve into the public, legal and theoretical debates about a society trying to change its violent relations for peaceful coexistence, in addition to covering the technicalities and explanations about its functioning and objectives.

On the one hand, the first cluster Transitional process indicates that 2016 featured the effort to decipher this new system and gave a frame of reference to the population on a complex and controversial concept, even though there may be differences between the information prioritized by each newspaper. El Tiempo, the conservative newspaper, is significantly associated with classes 2 and 1 ('Peace Agreement' and 'Justice'), where the emphasis appears to be on the main events and leaders of this process, as well as the legal consequences of the transitional justice system and the debate regarding possible instances of impunity for crimes against humanity during the search of truth. Meanwhile, the liberal newspaper El Espectador is significantly relevant for classes 7 and 8 ('Reaching Peace' and 'Power Relations'), which discuss the social transformations needed for more peaceful coexistence, the consequences of the peace agreement, as well as the changes in conflict dynamics regarding territorial and economic control once the guerrilla FARC demobilized. Moreover, the lexical universe regarding collective reparations seems to have no significant difference between newspapers (see Fig 2).

On the other hand, the second cluster reflects the victims' emphasis of the Colombian peace agreement, through which victims have public spaces to social share what happened. While this cluster focuses on collective action and highly emotional accounts of violence, class 3 ('Violence Testimonies') diverts from this frame as it portrays the voice of ex-combatants from previous peace processes that are testifying to clarify violent events and reach the truth. In addition, this class is the only one from the cluster associated with a newspaper, in this case, El Espectador.

\section{Study 2}

\subsection{Method}

Study 2 took place in Colombia during the implementation of the peace agreement (2019-2020). A questionnaire (online and on paper) was conducted to determine the perception of the TC and the JEP due to the institution's crucial role in the victims' reparation and the 
perpetrator's prosecution. We also explored psychosocial variables associated with the reconciliation process.

\subsection{Participants}

A cross-sectional descriptive correlational study was designed. The total sample was 1166 people from 22 of the 32 national departments. The age range of the participants was between 18 and 80 years old. $51.1 \%$ were university students, and over half of the sample were women. There is a higher percentage of women, participants with a middle level of education and predominantly from the center and leftwing (see Table 2).

Table 2

\section{Demographic Characteristics of the Sample}

\begin{tabular}{|c|c|c|c|}
\hline & Total Sample & Victims & Non-Victims \\
\hline Age: $M(S D)$ & $26.91(11.07)$ & $28.49(12.10)$ & $24.72(9.03)$ \\
\hline \multicolumn{4}{|l|}{ Gender } \\
\hline $\begin{array}{l}\text { Female } \\
\text { Male }\end{array}$ & $\begin{array}{l}64.2 \% \\
35.8 \%\end{array}$ & $\begin{array}{l}65.6 \% \\
34.2 \%\end{array}$ & $\begin{array}{l}61.9 \% \\
38.0 \%\end{array}$ \\
\hline \multicolumn{4}{|l|}{ Education } \\
\hline $\begin{array}{l}\text { High } \\
\text { Middle } \\
\text { Low }\end{array}$ & $\begin{array}{r}53.0 \% \\
41.1 \% \\
5.7 \%\end{array}$ & $\begin{array}{r}51.5 \% \\
40.6 \% \\
7.5 \%\end{array}$ & $\begin{array}{r}55.1 \% \\
41.8 \% \\
3.1 \%\end{array}$ \\
\hline \multicolumn{4}{|c|}{ Political Position } \\
\hline $\begin{array}{l}\text { Left } \\
\text { Center } \\
\text { Right }\end{array}$ & $\begin{array}{l}39.5 \% \\
45.6 \% \\
14.8 \%\end{array}$ & $\begin{array}{l}38.2 \% \\
44.7 \% \\
17.1 \%\end{array}$ & $\begin{array}{l}41.4 \% \\
46.9 \% \\
11.7 \%\end{array}$ \\
\hline $\mathrm{N}$ & 1.166 & 678 & 488 \\
\hline
\end{tabular}

Note: $\mathrm{N}=1166$. The valid percentage (\%) is reported. Education: Dichotomized according to three levels (High = University, Middle = Secondary, Technical and Technological, Low $=$ Not in school and Basic Primary). Political position: Categorized on a continuous scale 1-5 (Left $=1$ and 2, Center $=3$, Right $=4$ and 5).

Source: Table by Authors. 


\subsection{Procedure}

An adaptation of the previously used instrument on TC in Latin America (Arnoso et al. 2014, 2015; Cardenas et al. 2016; Espinosa et al. 2016) was made to the Colombian context and prepared through Google Forms platform. We also created a paper questionnaire with the same questions for country areas with internet accessibility problems. Subsequently, data collection began between January 2019 and January 2020 .

Administration time ranged from 35 to 50 minutes. Trained researchers applied the instrument. For the paper applications, the researcher deposited the data in the virtual database. Convenience sampling was used in all areas. Participation was voluntary, and the data collected were anonymized by numerical keys. All participants read and accepted the informed consent form.

\subsection{Measures}

Socio-demographic information. Age, gender, and education.

Political Position. Single ad hoc question. "Often when people talk about political issues, they use terms like "right-wing" or "left-wing" to describe their views. How would you define yourself according to these terms?" from 1 = Far Left to 5 = Far Right.

Violence Exposure. Dichotomous question on whether the participant had been a victim of collective violence because of the armed conflict.

Knowledge about the TC and the JEP. How much information they had about the TC and the JEP on a scale from $1=$ None to $6=$ Very much.

Transitional Justice information source. Eight items related to whether they have seen or heard information about the Commission and the JEP in different media (Radio, Newspapers, TV, social media). A scale from $1=$ None to $4=A$ lot, from each source and institution.

Approval of the TC and the JEP. Single ad hoc question "Regarding what the TC/JEP is going to do. You: "On a scale of 1 = Strongly disapprove to $4=$ Strongly approve.

Attitudes towards remembering. Two items with statements in favor of remembering violent events "When it comes to Colombia's past during the armed conflict, we must learn from the mistakes made to avoid making the same mistakes again" and in favor of forgetting "It is better not to open old wounds by talking about what happened in the past because of the armed conflict" with a scale of 1 = Completely false $/ 4$ = Completely true. 
Social Reconciliation. Adaptation of the scale of Wohl and Branscombe (2005) with the question "What would be necessary for reconciliation between the victims and those who caused them harm?" and eight statements related to the aspects necessary for reconciliation (e.g., That the perpetrators sincerely ask for forgiveness), on a scale of $1=$ Not at all $/ 4=$ Very much, $(\alpha=.85)$.

Social Sharing. Six items adapted from Rimé's (2012) scale related to the JEP, the TC, and the armed conflict (e.g., Have you talked about the TC with other people during the last month?).

Emotional climate. Four items related to the perception of the country's emotional climate on a scale from $1=$ Not at all to $4=$ Very much. It asks the level of perceived Solidarity, the general level of trust in institutions, the level of perceived anger or hostility, and the perceived sadness or passivity in the country.

Institutional Trust. Through a list of six governmental institutions (legislative branch, executive branch, judicial branch, departmental governments, local governments, political parties) and six nongovernmental institutions (trade unions, NGOs, TC, JEP, social leaders, and universities). Participants were asked the level of trust in each one on a scale from $1=$ Do not trust to $4=$ Very much trust $(\alpha=.85)$.

\subsection{Results}

\subsubsection{DESCRIPTIVE ANALYSIS}

The mean scores of the scales used, the reliability coefficient and the asymmetry and kurtosis are in Table 3. All coefficients were acceptable. The total sample includes $58.1 \%$ of people who reported having been victims of the armed conflict. No differences were found among the victims in terms of gender, educational level, or political position, although there were differences regarding age $\left[F(1,1164)=33.809 ; p=.0001 ; \eta^{2}=.028\right]$.

Approval levels were found to be higher than the theoretical average for the two transitional justice institutions (see Table 3). 21\% of the total sample reported fully supporting both institutions, while only $6.9 \%$ for the Commission and $9.8 \%$ for the JEP said they did not fully approve them. Regarding the information that people reported having about the two institutions, there is more information about the JEP than about the Commission, even so, in both cases, the scores do not surpass the theoretical average. 


\section{Table 3}

\section{Descriptive statistics, reliability coefficient ( $\alpha$ Cronbach), asymmetry, and kurtosis of the variables}

\begin{tabular}{lccccccc}
\hline \multicolumn{1}{c}{ Scales } & $\begin{array}{c}N^{\circ} \\
\text { items }\end{array}$ & $\alpha$ & Minimum & Maximum & Media (SD) & Asymmetry & Kurtosis \\
\hline TC Approval & 1 & - & 1.0 & 4.0 & $2.80(.85)$ & -.263 & -.596 \\
JEP Approval & 1 & - & 1.0 & 4.0 & $2.76(.90)$ & -.315 & -.656 \\
TC Information & 1 & - & 1.0 & 4.0 & $2.07(.90)$ & -.436 & -.682 \\
JEP Information & 1 & - & 1.0 & 4.0 & $2.27(.90)$ & -.238 & -.723 \\
Social Sharing & 5 & .78 & 1.0 & 3.83 & $1.81(.65)$ & -.540 & -.480 \\
Social Reconciliation & 8 & .83 & 1.0 & 4.0 & $2.87(.69)$ & -.629 & -.084 \\
Pro Collective Memory & 1 & - & 1.0 & 4.0 & $3.27(.94)$ & -1.090 & .107 \\
Against Collective Memory & 1 & - & 1.0 & 4.0 & $2.10(1.07)$ & -.498 & -1.06 \\
Positive Emotional Climate & 2 & .68 & 1.0 & 4.0 & $2.08(.73)$ & -.443 & -.185 \\
Negative Emotional Climate & 2 & .72 & 1.0 & 4.0 & $2.39(.79)$ & -.033 & -.597 \\
Government Confidence & 6 & .89 & 1.0 & 4.0 & $1.62(.54)$ & -.898 & 1.104 \\
Non-Governmental Confidence & 6 & .85 & 1.0 & 4.0 & $2.40(.69)$ & -.073 & -.383 \\
Transitional Justice Confidence & 2 & .90 & 1.0 & 4.0 & $2.36(.89)$ & -.093 & -.820 \\
\hline
\end{tabular}

Source: Table by authors.

The total sample presents high values in the reconciliation scale, which is related to the aspects necessary to achieve peaceful coexistence. Regarding the perceived emotional climate, participants report medium-low levels of positive emotional climate, with participants on the right-wing having higher scores in comparison with those on the left $(p=.001 ; d=0.27)$ and center-wing $(p=.024$; $d=0.20)\left[F(2,1145)=9.802 ; p=.0001 ; \eta^{2}=.017\right]$. In contrast, negative emotional climate scores are medium-high, with women reporting higher scores $\left[F(1,1147)=6.234 ; p=.013 ; \eta^{2}=.005\right]$. On the other hand, trust in government institutions has the lowest scores of all scales, however, trust in non-governmental institutions is close to the theoretical mean.

\subsubsection{Differences by Political Position}

Political position differences are present in the sample in several measures used (See Table 4). As per our hypothesis, people identified with the left-wing have higher scores regarding approval and information of transitional justice institutions, while people on the 
right-wing agree more with forgetting the past. However, there are no differences in the variable Pro Collective Memory, which refers to attitudes towards remembering the past for the non-repetition of violence.

In addition, we found differences in social sharing, with people on the left-wing reporting a greater need to talk about past violence and transitional justice institutions. Finally, people on the left-wing report higher levels of trust in nongovernmental and transitional justice institutions, while people on the right-wing perceive a more positive emotional climate; all of these differences are significant.

Table 4

Mean comparisons by political position

\begin{tabular}{lrrrrrr}
\hline \multicolumn{1}{c}{ Scales } & \multicolumn{1}{c}{ Left } & Center & Right & $\mathrm{F}$ & $\mathrm{p}$ & \multicolumn{1}{c}{$\eta^{2}$} \\
\hline TC Approval & $3.02 \mathrm{a}(.84)$ & $2.69 \mathrm{~b}(.80)$ & $2.63 \mathrm{~b}(.88)$ & 23.145 & .000 & .039 \\
JEP Approval & $2.99 \mathrm{a}(.89)$ & $2.63 \mathrm{~b}(.84)$ & $2.64 \mathrm{~b}(.94)$ & 22.730 & .000 & .038 \\
TC Information & $2.12(.88)$ & $2.04(.91)$ & $2.04(.95)$ & 1.207 & .299 & .002 \\
JEP Information & $2.38 \mathrm{a}(.91)$ & $2.18 \mathrm{~b}(.87)$ & $2.29(.91)$ & 5.863 & .003 & .010 \\
Social Sharing & $1.89 \mathrm{a}(.66)$ & $1.78 \mathrm{~b}(.62)$ & $1.73 \mathrm{~b}(.65)$ & 5.395 & .005 & .009 \\
Social Reconciliation & $2.92(.68)$ & $2.85(.70)$ & $2.80(.69)$ & 2.156 & .116 & .004 \\
Pro Collective Memory & $3.27(.96)$ & $3.29(.91)$ & $3.24(.96)$ & .177 & .838 & .000 \\
Against Collective Memory & $1.99 \mathrm{~b}(1.0)$ & $2.12 \mathrm{~b}(1.0)$ & $2.34 \mathrm{a}(1.1)$ & 6.806 & .001 & .012 \\
Positive Emotional Climate & $1.98 \mathrm{a}(.69)$ & $2.12 \mathrm{~b}(.71)$ & $2.26 \mathrm{c}(.81)$ & 10.098 & .000 & .017 \\
Negative Emotional Climate & $2.43(.77)$ & $2.38(.79)$ & $2.31(.84)$ & 1.576 & .207 & .003 \\
Government Confidence & $1.60(.53)$ & $1.61(.53)$ & $1.70(.56)$ & 2.682 & .069 & .005 \\
Non-Governmental Confidence & $2.53 \mathrm{a}(.74)$ & $2.35 \mathrm{~b}(.63)$ & $2.26 \mathrm{~b}(.67)$ & 13.337 & .000 & .023 \\
Transitional Justice Confidence & $2.53 \mathrm{a}(.91)$ & $2.27 \mathrm{~b}(.82)$ & $2.24 \mathrm{~b}(.92)$ & 13.004 & .000 & .022 \\
\hline
\end{tabular}

N $\quad 450 \quad 520 \quad 172$

Note. Different letters indicate statistically significant differences (post-hoc DMS, $p \leq .05$.

Source: Table by Authors.

\subsubsection{ANALYSIS BY SOURCE OF INFORMATION}

We also explored which sources of information the respondents had seen, heard, or read about the Commission and the JEP. The 
political position had differences in the Newspapers and Social Media sources, with people on the Left-wing reporting having received more information than people on the Right and Center-wing (see Table 5).

Table 5

Mean comparisons between political positions regarding source of information

\begin{tabular}{lcccccc}
\hline $\begin{array}{c}\text { Truth } \\
\text { Commission }\end{array}$ & Left & Center & Right & F & p & $\eta^{2}$ \\
\hline Television & $2.03(.83)$ & $2.09(.87)$ & $2.16(.92)$ & 1.538 & .215 & .003 \\
Radio & $1.80(.87)$ & $1.75(.88)$ & $1.83(.94)$ & 0.728 & .483 & .001 \\
Newspapers & $1.89(.92)$ & $1.77(.86)$ & $1.69(.83)$ & 3.969 & .019 & .007 \\
Social Media & $2.19(1.0)$ & $2.02(.97)$ & $1.99(.97)$ & 4.682 & .009 & .008 \\
\hline JEP & & & & & & \\
$\quad$ Television & $2.39(.90)$ & $2.40(.91)$ & $2.47(.91)$ & 0.448 & .639 & .001 \\
Radio & $2.04(.94)$ & $1.97(.94)$ & $2.01(.96)$ & 0.735 & .480 & .001 \\
Newspapers & $2.13(.99)$ & $1.90(.87)$ & $1.85(.91)$ & 9.152 & .000 & .015 \\
Social Media & $2.41(1.0)$ & $2.21(.96)$ & $2.08(.94)$ & 8.468 & .000 & .014 \\
\hline
\end{tabular}

Source: Table by authors.

\subsubsection{Correlational Analysis}

The Pearson correlation between the variables studied is shown in Table 6 . The variables directly related to transitional justice institutions (Information, Approval, and Trust) have positive correlations yet have some important differences with other variables. First, information about the TC and the JEP correlates positively with all variables except for the political position and unfavorable attitudes towards collective memory. In contrast, approval of these institutions correlates negatively with a political position, negative emotional climate, and institutional trust. Similarly, trust in the TC and the JEP has negative correlations with political position and "against collective memory" and a positive correlation with the other variables in the study. 


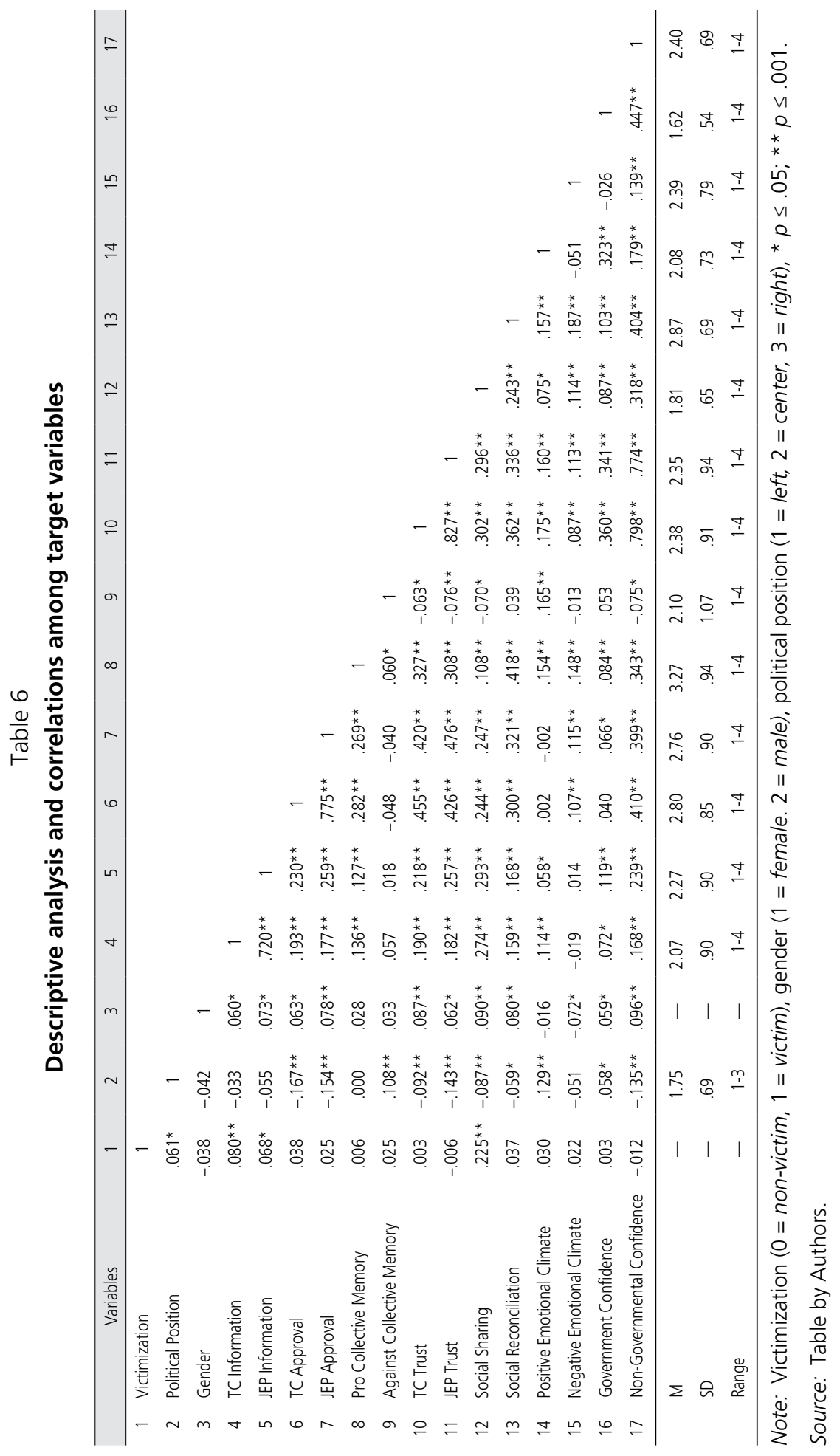


Victimization is positively related to information about the two transitional justice institutions, the need for social sharing, and political position. Furthermore, people identified with the left-wing have higher approval levels towards the TC and the JEP, a greater need for social sharing, a higher agreement with the need for reconciliation between victims and perpetrators, and a greater trust in non-governmental institutions. On the other hand, people on the right-wing have attitudes against collective memory, perceive a better emotional climate in the country, and trust government institutions more.

Regarding social sharing, it has a positive correlation with all the variables except with political position and "against collective memory" to which it correlates negatively. The same pattern occurs in social reconciliation. Finally, the negative emotional climate correlates negatively with gender and positively correlates with approval and trust towards the TC and the JEP.

\subsection{Conclusions}

The results suggest that victims are also the population group with the greatest need to talk about the armed conflict and the transitional justice institutions. Previous experiences show that making victims visible fosters favorable attitudes towards reconciliation in the general population (Mathias et al. 2020). Consequently, the results also indicate that victims are more informed and supportive of these institutions and more approving of their work. Similar to studies on the 2016 referendum, which found that populations in conflict zones show higher support for the peace process in general compared to other sectors of the population (Tellez 2018).

In Colombia, the political orientation is critical to understanding how people read the context and the country's situation, even more so, considering that the current government does not support the peace agreement or the transitional justice institutions (Flores and Vargas 2018). An example of this is the substantial differences exposed in all the variables analyzed in study 2 regarding the political position. Like other Latin American countries (Mathias et al. 2020), left-leaning people have more approval, information, and support towards the TC and JEP. They also report a greater need for social sharing and less agreement with an attitude of forgetfulness towards the country's violent past. They also report seeing more information about these institutions in all media. Interestingly, right-leaning people agree more with attitudes towards forgetting what happened during the conflict 
and perceive a more positive emotional climate. This finding could be understood as a tendency to downplay the importance of the armed conflict memory and the need to talk openly about the facts of the conflict, consistent with contexts with guerrilla involvement (Mathias et al. 2020).

The armed conflict memory requires public and narrative spaces to discuss what happened and attempt to explain the how and why of the war as a collective effort in society (Martín-Beristain et al. 2010; Velez et al. 2020). Hence, our findings show social sharing (i.e., the need to talk about the conflict and transitional justice) is fundamental for the approval and confidence of the TC and JEP and memory construction. It is also related to institutional trust and emotional climate (positive and negative). Interestingly, people that trust non-governmental institutions also trust the TC and the JEP, have a higher need for social sharing, and a higher agreement with reconciliation processes. These results suggest that even when transitional justice institutions emerge from state policies, they appear as highly independent in their functions and objectives, which could also explain why low levels of trust in governmental institutions do not affect confidence in the JEP and the TC. However, this relationship between variables relates to a political position, with people on the left-wing having the highest levels of trust in non-governmental institutions.

\section{General discussion}

The search for social restructuring and peaceful coexistence through institutions that address the problem of war from its complexity is not only relevant but urgent and necessary for a country that seeks to confront a violent past (Bar-Tal 2011; Martín-Beristain et al. 2010). This article explored transitional justice conceptions in Colombia during two specific moments: the consolidation of the peace agreement during 2016 (study 1) and its subsequent implementation during 2019-2020 (study 2). The studies conducted help make social representations of transitional justice and attitudes towards its institutions visible through two primary sources of information.

Firstly, from the media, which have shown to be crucial for the structuring of opinions in favor or against peace culture building processes (López-López et al. 2014; López-López et al. 2021) and which are a fundamental piece in the representation of reality and in the perceptions that the general population constructs concerning the war and the transition process (Igartua 2011). Secondly, through 
a broad sample collected throughout the country that evaluates the general population conceptions regarding approval, trust, and level of information on transitional justice institutions, in addition to inquiring about psychosocial variables that are relevant to understand the impact of these models in Latin America (Arnoso et al. 2015; Velez et al. 2020).

The findings of both studies support the idea that political position is a relevant factor in the way transitional justice acts in Colombia. This political variable seems to influence the narrative regarding peace and armed conflict. The left-wing or more liberal political positions have more favorable attitudes towards transitional institutions and more complex and multidimensional descriptions of the peace agreement.

In contrast, more conservative or right-wing positions show more instrumental descriptions of the transition process and agree more with not discussing the past as the appropriate way to approach the end of the conflict. Also, the results show that there is an interesting difference between how the country is perceived. On the one hand, the more liberal newspaper tends to have news that describes the social reality of the country and analyze the conflict and the consequences of the current historical moment; likewise, people on the left show a greater need to talk about the armed conflict and a less positive emotional climate. On the other hand, the more conservative newspaper opts for more instrumental news about the developments of the peace agreement and delves into the legal processes related to impunity and crimes against humanity; similarly, people on the right have less need to talk about the past, approve and know less about the institutions of transitional justice.

Thus, in the conservative newspaper El Tiempo, the lexical analysis shows that transitional justice is anchored in legal justice, emphasizing the work of political and armed leaders as the main actors in the peace process. In other words, the discourse focuses on reducing the culture of impunity and accountability (Lambourne 2009), specifically on the effectiveness and guarantees of the new justice system concerning crimes against humanity. Hence, there is no recognition of the other, the FARC guerrillas or their interests, as necessarily a socio-political subject, but rather a concern for the consequences of their acts and the legal processes they must face in the process of reinsertion into civilian life.

Likewise, previous studies in conflict contexts such as the IsraelPalestinian conflict (Leshem 2017) found that people on the right-wing political position preferred more abstract definitions of peace to avoid the psychological cost of recognizing the other. 
Meanwhile, the liberal newspaper El Espectador anchored transitional justice in psychosocial and political aspects of the conflict and the expectations for the future after the peace agreement. Peace is portrayed as a longitudinal process that requires social changes to be achieved and includes the various actors in the conflict and their power relations. This discourse is an effort to recognize the different groups as socio-political actors that should be included in the transitional process to achieve peaceful coexistence. Therefore, sharing the testimonies of illegal armed groups from previous peace processes contributes to the search for truth and the construction of collective memory, even though the socio-emotional cost of this social sharing may be high.

This involvement of the media in memory reconstruction processes has been of vital importance in other countries that have implemented transitional justice models. Such as the case of Rwanda, where media encouraged contact between groups and the reduction of negative stereotypes in the medium and long term, even if there is a short-term impact on the emotional climate and well-being of group members (Paluck 2009).

Similarly, the differences in the political position of the participants in study 2 also reflect two different approaches to the transitional justice model. In Colombia, right-wing political parties have been the primary opponents of the agreement (Kajsiu 2019), affecting people's perceptions due to their political position. Thus, it makes sense that the profile of a person with right-wing political tendencies in Colombia is more skeptical about these institutions (approving less of their work and having less information about them), prefers not to talk about the past, and perceives the country with a more positive emotional climate. In other words, the intense debates that the country experienced since 2016 about the peace agreement reflected in the newspapers seem to linger in the perceptions of the general population and linked in both cases to a specific political vision where each group understands the end of the conflict and peacebuilding from different anchoring categories.

Finally, we acknowledge that this paper has significant limitations. The two studies conducted were not carried out consecutively (20162019). Even though the methodologies used are complementary, they are not comparable as they use two different sources (Newspapers and surveys). In future studies, an analysis of data from the same period could provide a more specific perspective of this object. However, the current findings contribute to building a global understanding of transitional justice in Colombia. On the other hand, the selected newspapers do not represent the totality of the debates during 2016 
regarding the peace agreement. Since they are national newspapers with the largest audience, they do not reflect the discourses outside the mainstream. However, they can provide a general context of the transitional justice concepts and their treatment in public debates.

In conclusion, social reconciliation relies on acknowledging the damage caused, and on the shared memory of the violent past in which the groups (e.g., former armed groups, victims) involved feel included and represented (Gluecker et al. 2021). This process, which uses transitional justice as one of its fundamental tools, can be affected when individuals and groups devalue what occurred and prefer to silence and make the damage and pain of other groups invisible. Hence, the influence of political position in the social representations and attitudes towards transitional justice may create different understandings of peace, which in turn can disseminate both a discourse that contributes to the collective construction of more peaceful societies or narratives that evade the recognition of the other, the violent past and the need to social share what happened.

\section{References}

Allum, Nick. 1998. "A social representations approach to the comparison of three textual corpora using alceste.» Dissertation, University of London.

Alarcón, Oscar. 2020. "El Espectador cumplió 133 años de fundado: La difícil vida de un diario.» El Espectador, March 31. Accessed 09-24-2021. https:// www.elespectador.com/entretenimiento/cine-y-tv/el-espectador-cumplio133-anos-de-fundado-la-dificil-vida-de-un-diario-article-912263/.

Alzate, Mónica, and Marcos Dono. 2017. «Reconciliación social como estrategia para la transformación de los conflictos socio-políticos. Variables asociadas e instrumentos de medición.» Universitas Psychologica 16, no. 3 : 1-10. https://doi.org/10.11144/javeriana.upsy16-3.rset.

Arnoso, Maitane, Manuel Cárdenas, Darío Páez y Carlos Martín Beristain. 2014. «Paraguay: De las violaciones a los derechos humanos a la justicia transicional.» Salud \& Sociedad 5, no. 1: 98-114. https://www.redalyc.org/ articulo.oa?id=439742474006.

Arnoso, Maitane, Darío Páez, Manuel Cárdenas, Elena Zubieta, Agustín Espinosa, and Marian Bilbao. 2015. «Representaciones sociales del pasado y rituales de justicia transicional en América Latina.» Cadernos de Pesquisa 45, no. 156: 276-98. https://doi.org/10.1590/198053143134.

Bar-Tal, Daniel. 2011. Intergroup conflicts and their resolution: a social psychological perspective. New York: Psychology Press.

Bohigues, Asbel, José Manuel Rivas, and Sergio García. 2021. «Elite support for peace agreements: evidence from Colombia.» Peacebuilding, 1-19. https://doi.org/10.1080/21647259.2021.1956751. 
Buckley-Zistel, Susanne, Koloma T. Beck, Christian Braun, and Friederike Mieth. 2015. Transitional Justice Theories. London: Routledge.

Camargo, Brigido V., and Andréa B. Bousfield. 2009. "Social representations, risk behaviors and AIDS.» The Spanish Journal of Psychology 12, no. 2: 565-75. https://doi.org/10.1017/s1138741600001931.

Cárdenas, Manuel, Elena Zubieta, Darío Páez, Maitane Arnoso, and Agustín Espinosa. 2016. "Determinants of approval of the work of Truth Commissions in the Southern Cone: A comparative study.» Revista de Psicología Social 31, no. 3: 423-62. https://doi.org/10.1080/02134748.20 16.1190127.

Editorial. 2018 «Motivos De Un Respaldo a Iván Duque.» El Tiempo. El Tiempo, June 9. https://www.eltiempo.com/opinion/editorial/motivos-deun-respaldo-a-ivan-duque-228530.

El Espectador. 2021. "Colombia +20: Noticias del conflicto armado en Colombia, procesos de paz y la Jep.» ELESPECTADOR.COM. Accessed November 12, 2021. https://www.elespectador.com/colombia-20/.

Espinosa, Agustín, Darío Páez, Tesania Velázquez, Rosa Ma Cueto, Evelyn Seminario, Salvador Sandoval, Félix Reátegui, and Iris Jave. 2016. «Between remembering and forgetting the years of political violence: Psychosocial impact of the Truth and Reconciliation Commission in Peru.»Political Psychology 38, no. 5: 849-66. https://doi.org/10.1111/ pops.12364.

Flores, Thomas E., and Juan F. Vargas. 2018. «Colombia: Democracy, violence, and the peacebuilding challenge.»C Conflict Management and Peace Science 35, no. 6: 581-86. https://doi.org/10.1177/0738894218787786.

Forbes. 2020. «Millonarios Colombia 2020.» Forbes Colombia, July 8, 2020. https://forbes.co/millonarios-colombia-2020/.

Fundación Paz y Reconciliación. 2019. Más sombras que luces. La seguridad en Colombia a un año del gobierno de Iván Duque. Bogotá, Colombia. https://pares.com.co/wp-content/uploads/2019/08/Que\%CC\%81paso \% CC \%81-con-la-seguridad-a-un-an\% CC \%83o-de-Duque-final-_ compressed-Final.pdf

Galtung, Johan. 1969. "Violence, peace, and peace research.» Journal of Peace Research 6, no. 3: 167-91. http://www.jstor.org/stable/422690

Gluecker, Andreas, Andrea Correa-Chica, and Wilson López-López. 2021. "The FARC in Colombia: Collective reintegration and social identity transformation.» Political Psychology. https://doi.org/10.1111/pops.12765.

Grajales, Gloria M., and Javier O. Martínez. 2020. «Tendencias, trayectorias y relaciones de poder en el discurso de construcción de paz en el periódico El Espectador (Colombia).» El Ágora USB 20, no. 1. 112-29. https://doi. org/10.21500/16578031.4184.

Gutiérrez-Romero, Mario F., Wilson López-López, and Luis M. Silva. 2020. «Preferencia hacia la justicia restaurativa y retributiva y su relación con el nivel de competencia Moral.» Suma Psicológica 27, no. 2. https://doi. org/10.14349/sumapsi.2020.v27.n2.5. 
Gutiérrez-Romero, Mario Fernando, Wilson López-López, Alejandra OrjuelaGarcía, and Andrea Escobar-Altare. 2021. "Representaciones sobre la justicia: Un estudio comparativo en escolares colombianos.» Revista de Psicología 39, no. 2: 655-86. https://doi.org/10.18800/psico.202102.006 .

Igartua, Juan José. 2011. «Comunicación mediática, persuasión narrativa y educación para la paz.» In Superando La Violencia Colectiva y Construyendo Cultura De Paz, edited by Darío Páez, Carlos MartínBeristain, José Luis González, Nekane Basabe, and Joseph de Rivera, 631-68. Madrid: Fundamentos.

Kajsiu, Blendi. 2019. "The Colombian Right: The political ideology and mobilization of Uribismo.» Canadian Journal of Latin American and Caribbean Studies 44, no. 2: 204-24. https://doi.org/10.1080/08263663.2 019.1581495.

Kelman, Herbert C., Philip Mattar, and Neil Caplan. 2018. Transforming the Israeli-Palestinian Conflict: From Mutual Negation to Reconciliation. London: Routledge.

Klein, Olivier, and Laurent Licata. 2003. "When group representations serve social change: The speeches of Patrice Lumumba during the Congolese decolonization.» British Journal of Social Psychology 42, no. 4: 571-93. https://doi.org/10.1348/014466603322595284.

Jurisdicción Especial para la Paz. 2019. «Sistema integral de verdad, justicia, reparación y no repetición (SIVJRNR)». Accessed September 10, 2021. https://www.jep.gov.co/Infografas/SIVJRNR_ES.pdf

Lambourne, Wendy. 2009. "Transitional justice and peacebuilding after mass violence.» International Journal of Transitional Justice 3, no. 1: 28-48. https://doi.org/10.1093/ijtj/ijn037

Leshem, Oded A. 2017. "What you wish for is not what you expect: Measuring hope for peace during intractable conflicts.» International Journal of Intercultural Relations 60: 60-66. https://doi.org/10.1016/j. ijintrel.2017.06.005

Leshem, Oded A., and Eran Halperin. 2020. «Lay theories of peace and their influence on policy preference during violent conflict.» Proceedings of the National Academy of Sciences 117, no. 31: 18378-84. https://doi. org/10.1073/pnas.2005928117

López-López, Wilson, and José M. Sabucedo. 2007. "Culture of peace and mass media.» European Psychologist 12, no. 2: 147-55. https://doi. org/10.1027/1016-9040.12.2.147

López-López, Wilson, José M. Sabucedo-Cameselle, Idaly Barreto, Yeny Serrano, and Henry Borja. 2014. "Discourse as a strategy for the construction of peace cultures.» In Psychosocial Approaches to PeaceBuilding in Colombia, edited by Stella Sacipa-Rodriguez and Maritza Montero, 1st ed., 111-120. City: New York. Springer.

López-López, Wilson. 2017. "Contribuciones de psicología de la paz: una perspectiva multidimensional.»Innovación y Ciencia XXIV, no. 1: 100-108. https://innovacionyciencia.com/revistas_pdf/2017-1.pdf 
López-López, Wilson, Claudia Pineda-Marín, Andrea Correa-Chica and Camilo Rincón-Ungaro. 2021. "Psychology of peace: findings and challenges for the multidimensional transformation of violent social practices.». In Political Psychology in Latin America, edited by Claudia Zuñiga and Wilson López-López, 1st ed., 131-50. Washington DC: American Psychological Association. https://doi.org/10.1037/0000230-007

Martín-Beristain, Carlos, Darío Páez, Bernard Rimé, and Patrick Kanyangara. 2010. "Psychosocial effects of participation in rituals of transitional justice: A collective-level analysis and review of the literature of the effects of Trcs and trials on human rights violations in Latin America.» Revista de Psicología Social 25, no. 1: 47-60. https://doi. org/10.1174/021347410790193450

Matanock, Aila M., and Miguel García-Sánchez. 2017 «The Colombian paradox: peace processes, elite divisions \& popular plebiscites.» Daedalus 146, no. 4: 152-66. https://doi.org/10.1162/daed_a_00466.

Mathias, Anderson, Darío Páez, Agustín Espinosa, Salvador Sandoval, Carolina Alzugaray, Maitane Arnoso, Manuel Cárdenas et al. 2020. "The association between Truth Commissions evaluation, emotional climate and institutional trust: comparison and meta-analysis of surveys in six South American Countries.» International Journal of Social Psychology 35, no. 2: 203-45. https://doi.org/10.1080/02134748.2020.1721053.

Paluck, Elizabeth. 2009. "Reducing intergroup prejudice and conflict using the media: A field experiment in Rwanda.» Journal of Personality and Social Psychology 96, no. 3: 574-587. https://doi.org/10.1037/a0011989

Reinert, Max. 1996. Alceste (Version 3.0). Toulouse: Images.

Reinert, Max. 1993. "Les 'Mondes Lexicaux' Et Leur 'Logique' à Travers L'analyse Statistique D'un Corpus De Récits De Cauchemars.» Langage \& société 1, 66: 5-39. https://www.persee.fr/doc/lsoc_0181-4095_1993_ num_66_1_2632

Reinert, Max. 1990. "Alceste Une Methodologie D'analyse Des Donnees Textuelles Et Une Application: Aurelia De Gerard De Nerval.», Bulletin De Méthodologie Sociologique 26: 24-54. Accessed September 10, 2021. http://www.jstor.org/stable/24362247

Reinert, Max A. 1983. "Une méthode de classification descendante hiérarchique: Application à l'analyse lexicale par contexte.» Les Cahiers de l'Analyse des D onnées 2, no. 8: 187-98.

Rettberg, Angelika, and Juan E. Ugarriza. 2016. "Reconciliation: A comprehensive framework for empirical analysis.» Security Dialogue 47, no. 6: 517-40. https://doi.org/10.1177/0967010616671858

Rimé Bernard. 2012. La compartición social de las emociones. Bilbao: Desclée de Brouwer. https://www.edesclee.com/img/cms/pdfs/9788433025777.pdf

Rincón-Unigarro, Camilo, Andrea Correa-Chica, Wilson López-López, María Morales-Sierra, and Sara Rivera-Escobar. 2020. «Encuadres mediáticos del perdón y reconciliación en el contexto del conflicto armado colombiano.» Revista Colombiana de Psicología 29, no. 1: 105-23. https:// doi.org/10.15446/.v29n1.81505. 
Staub, Ervin.2012. "Genocide, mass killing, and violent conflict: Prevention and reconciliation.» In The Oxford Handbook of Intergroup Conflict, edited by Linda R. Tropp, 1st ed., 309-27. Oxford: Oxford University Press, https://www.oxfordhandbooks.com/view/10.1093/ oxfordhb/9780199747672.001.0001/oxfordhb-9780199747672-e-16

Tellez, Juan Fernando. 2018. «Worlds apart: Conflict exposure and preferences for peace.» Journal of Conflict Resolution 63, no. 4: 1053-76. https://doi. org/10.1177/0022002718775825

Trejos, Luis F. 2013. "Colombia: Una revisión teórica de su conflicto armado.» Revista Enfoques 18, XI: 55-75.

Wohl, Michael J.A., and Nyla R. Branscombe. 2005. «Forgiveness and collective guilt assignment to historical perpetrator groups depend on level of social category inclusiveness.» Journal of Personality and Social Psychology 88, no. 2: 288-303. https://doi.org/10.1037/0022-3514.88.2.288

Velez, Gabriel, Gabriel Twose, and Wilson López-López. 2020. «Human rights and reconciliation: theoretical and empirical connections.» In The Cambridge Handbook of Psychology and Human Rights, edited by Neal S. Rubin and Roseanne L. Flores, 537-52. Cambridge: Cambridge University Press. doi:10.1017/9781108348607.037 


\section{Copyright}

Deusto Journal of Human Rights / Revista Deusto de Derechos Humanos is an Open Access journal; which means that it is free for full and immediate access, reading, search, download, distribution, and reuse in any medium only for non-commercial purposes and in accordance with any applicable copyright legislation, without prior permission from the copyright holder (University of Deusto) or the author; provided the original work and publication source are properly cited (Issue number, year, pages and DOI if applicable) and any changes to the original are clearly indicated. Any other use of its content in any medium or format, now known or developed in the future, requires prior written permission of the copyright holder.

\section{Derechos de autoría}

Deusto Journal of Human Rights / Revista Deusto de Derechos Humanos es una revista de Acceso Abierto; lo que significa que es de libre acceso en su integridad inmediatamente después de la publicación de cada número. Se permite su lectura, la búsqueda, descarga, distribución y reutilización en cualquier tipo de soporte sólo para fines no comerciales y según lo previsto por la ley; sin la previa autorización de la Editorial (Universidad de Deusto) o la persona autora, siempre que la obra original sea debidamente citada (número, año, páginas y DOI si procede) y cualquier cambio en el original esté claramente indicado. Cualquier otro uso de su contenido en cualquier medio o formato, ahora conocido o desarrollado en el futuro, requiere el permiso previo por escrito de la persona titular de los derechos de autoría. 